A Legacy of Leadership 
Commemorating the Centennial of the

National Governors Association

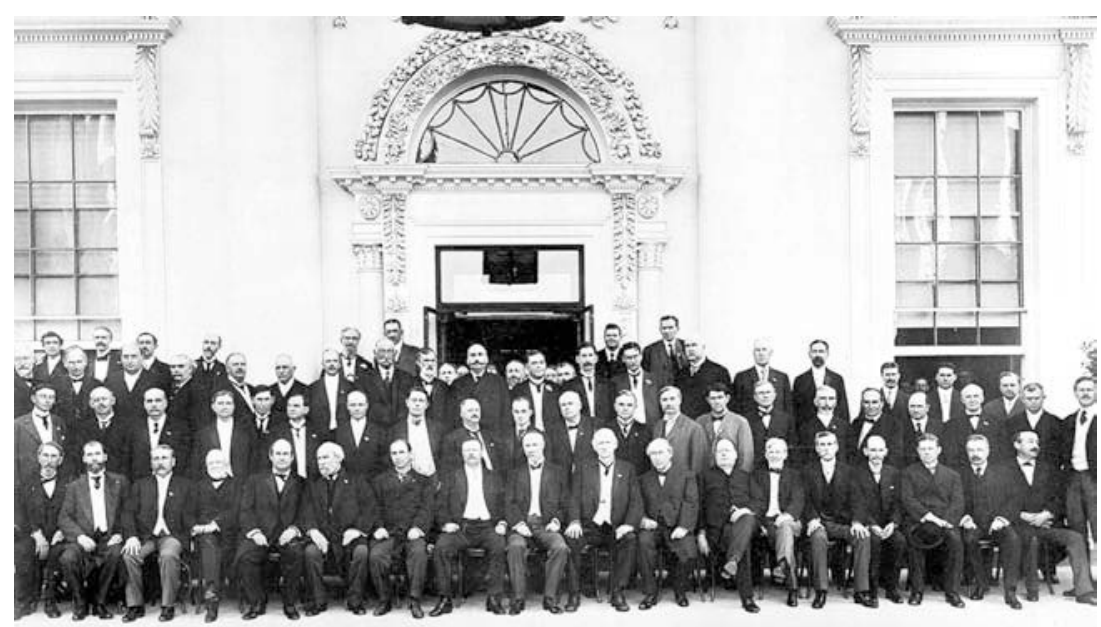

Governors at the White House, May 13-15, 1908 


\section{A Legacy of Leadership}

Governors and American History

E D I T E D B Y

CLAYTON MGCLURE BROOKS

$\overline{\text { PENN }}$

University of Pennsylvania Press

Philadelphia 
Copyright (C) 2008 University of Pennsylvania Press

All rights reserved. Except for brief quotations used for purposes of review or scholarly citation, none of this book may be reproduced in any form by any means without written permission from the publisher.

Published by

University of Pennsylvania Press

Philadelphia, Pennsylvania 19104-4112

The views expressed here are those of the authors and do not necessarily represent those of the National Governors Association or the Woodrow Wilson Presidential Library.

Printed in the United States of America on acid-free paper

$\begin{array}{llllllllll}10 & 9 & 8 & 7 & 6 & 5 & 4 & 3 & 2 & 1\end{array}$

Library of Congress Cataloging-in-Publication Data

A legacy of leadership : governors and American history / edited by Clayton McClure

Brooks.

p cm.

Includes bibliographical references and index.

ISBN 978-0-8122-4094-8 (hardcover : alk. paper)

1. Governors-United States-History-20th century. 2. United States-Politics and government-20th century. 3. Women governors-United States. 4. Decentralization in government-United States-History-20th century. I. Brooks, Clayton McClure.

JK2447.L45 2008

$973.9092^{\prime} 2-\mathrm{dc} 22$

2008000035

Frontispiece: Governors at the White House, May 13-15, 1908. Invited by President (and former governor) Theodore Roosevelt to discuss conservation issues, governors assembled for this group photograph outside the White House. Roosevelt is seated near the middle of the first row. The president and governors are joined by cabinet members, Supreme Court justices, and other dignitaries, including Andrew Carnegie and William Jennings Bryan (seated fourth and fifth from left in first row). Reprinted with permission of the National Governors Association. 